\title{
Building an Intention Model Using the Grab Health Application During the Covid-19 Pandemic
}

\author{
Didik Setyawan \\ Program Studi S1 Manajemen \\ Fakultas Ekonomi, Universitas Setia Budi \\ Surakarta, Indonesia \\ didiksetyawan1977@gmail.com \\ Maria Lusia Viany Noe \\ Program Studi S1 Manajemen \\ Fakultas Ekonomi, Universitas Setia Budi \\ Surakarta, Indonesia \\ lusianoe1983@gmail.com
}

\author{
Nang Among Budiadi \\ Program Studi S1 Manajemen \\ Fakultas Ekonomi, Universitas Setia Budi \\ Surakarta, Indonesia \\ nangamongbudiadi@gmail.com \\ Budi Setyanta \\ Program Studi Manajemen \\ Fakultas Ekonomi dan Bisnis Universitas Janabadra \\ Yogyakarta, Indonesia \\ budi@janabadra.ac.id
}

\begin{abstract}
This study aims to identify the variables that form the intention model of using the Grab Health application during the Covid-19 pandemic. The Covid-19 pandemic forces individuals to spend less at drugstores and pharmacies so that health product shopping applications have the opportunity to gain abundance. Sampling by convenience through a research questionnaire numbered 200 to meet the requirements of the Structural Equation Modeling (SEM) test. The results of this study indicate that attitudes influence the intention to use the Grab Health application. Perceived enjoyment and social influence play an important role in attitudes, although vulnerability is not a variable that influences attitudes.
\end{abstract}

Keywords: Behavioral Intentions, Attitudes, Perceived Enjoyment, Social Influences, Perceived Vulnerability

\section{INTRODUCTION}

Pandemics have the potential to increase morbidity and mortality and reduce economic growth due to changes in consumer behavior. Individuals limit their outdoor activities and work in offices for fear of being infected [1]. Pandemics have the potential to changes consumer behavior. Individuals limit their outdoor activities and work in offices for fear of being infected [2] The government adopted emergency policies swiftly to force people to comply with the new norms [3].

The perceived risk of being infected by covid-19 and the implementation of regulations restricting people's activities outside the home are an advantage for online shopping applications. One of the online shopping applications that have the potential to benefit from the pandemic is Grab Health Powered by Good Doctor. The increase in user traffic for Grab Health during the pandemic by 20 times, and questions about Covid-19 increased by $400 \%$ [4] are attractive phenomena to research. This research is to identify the intention to use the Grab Health application in Solo.

Previous studies have indicated a gap in the relationship between social influence and intention to use information systems on various research objects [5]. The study of [5] indicates that social influence does not affect the intention to use information system applications, on the contrary. The diversity of research results is due to differences in problems and backgrounds. This study reconfirmed the relationship between the two variables in a different setting. This study develops a research model from [6], [7], and [8] by adding attitude variables [7] and [9] as a mediator variable perceived convenience, social influence, and perceived vulnerability to the intention to use information systems.

\section{LITERATURE REVIEW}

\section{A. Behavioral Intention}

The intention is conceptualized as an individual's assessment to perform a specific behavior [10], so that behavioral intention is an individual's perception to carry out a particular action based on his owns desires. In the context of using information systems, the intent is to understand an individual's readiness to use an information system [11].

\section{B. Behavioral Intention}

Attitudes are positive or negative feelings that arise from individual experiences that have an impact on their environment [12]. The manner refers to an individual's sense of like or dislike for an object that leads to behavior [13].

This study conceptualizes attitudes as individual assessments of positive or negative feelings towards online applications. Previous research indicated a positive effect of attitudes on the intention to use information systems 
[14];[15];[7]. The high attitude as a form of individual evaluation of objects has an impact on increasing the intention to use online applications.

$\mathrm{H} 1$ : Individual intention to use information systems is getting higher because information systems make it easy to transact and obtain information.

\section{Perceived Enjoyment}

Perceived enjoyment is an individual's assessment of a particular behavior, which is influenced by extrinsic and intrinsic factors [16]. The Perceived enjoyment of using technology is an individual evaluation of the use of information systems that ignores the performance of the information technology systems, provides pleasant or unpleasant [17]. This study conceptualizes perceived enjoyment as an individual assessment that using information systems provides flexibility and fun. Previous research indicated that attitudes mediate perceived enjoyment towards behavioral intentions [18]. The study shows that perceived enjoyment affects an individual's assessment and evaluation of information systems. Individuals tend to have a positive attitude towards information systems that are fun and easy to operate.

$\mathrm{H} 2$ : Information systems that provide enjoyment and fun increase positive attitudes towards information systems

\section{Social Influence}

Social influence measures behavior that is influenced by others [19]; Chatrine et al., 2017). In the context of using information systems, social influence is the belief that other people are in the technology information system [20], and want to continue to use it [21]. This study defines social influence as an individual's perception of the use of information systems that are influenced by the belief that other people continue to use information systems. Individual assessment and evaluation of the use of information systems are influenced by the experiences of others who use information systems [22]; [23]; [24]; [25].

H3: The belief and evaluation that other people continue to use information systems increase positive attitudes towards information systems.

\section{E. $\quad$ Perceived Vulnerability}

Perceived vulnerability is the potential for effectless events that impact work and welfare [26]; [27]; [28], including privacy threats [29]. This study defines perceived vulnerability as an individual's assessment of opportunities for privacy threats and virus intrusions in the use of information systems. Internet users' privacy violations have an impact on individual attitudes not to publish personal information on the internet [30]. Individuals who feel vulnerable tend to avoid using information systems. Perceptions of vulnerability to the use of adverse information systems reduce attitudes to use information systems [31].
H4: The use of information systems that are detrimental to privacy reduces a positive attitude towards information systems.

\section{RESEARCH METHOD}

This study examined the causal relationship between variables using cross-sectional data. The collecting data in this research using convenience techniques sampling through an online questionnaire. The research sample of 200 Grab Health application users to meet the sample adequacy requirements in the Structural Equation Model (SEM) test.

\section{RESULT}

Causality research aims to identify the causal relationship between variables. To find out whether the independent variable has a significant effect on the dependent variable through the value of the critical factor. At the 5\% significance level, the cut off critical factor (CR) value was 1.96. The independent variable has a significant effect on the dependent variable if the statistical CR value is more than 1.96 .

TABLE 1. STATISTICAL TEST RESULT

\begin{tabular}{|c|c|c|c|}
\hline Hypothesis & Estimate Standard & cr & Probability \\
\hline $\mathrm{Att} \rightarrow \mathrm{BI}$ & 0,107 & 8,023 & $* * *$ \\
\hline $\mathrm{PE} \rightarrow \mathrm{Att}$ & 0,072 & 7,552 & $* * *$ \\
\hline $\mathrm{SI} \rightarrow \mathrm{Att}$ & 0,049 & 6,421 & $* * *$ \\
\hline $\mathrm{PV} \rightarrow \mathrm{Att}$ & 0,023 & $-0,445$ & 0,656 \\
\hline
\end{tabular}

\section{DISCUSSION}

This study indicates that attitudes have a positive effect on the intention to use the Grab Health application. H1 is supported. The belief and evaluation of individuals that the Grab Health application provides convenience and flexibility in purchasing drugs and obtaining health information from credible sources have an impact on the intention to use the Grab Health application during the Covid-19 pandemic.

This study support [32] that attitudes towards content quality and the usefulness of information system applications have a positive impact on behavioral intention. An attitude is an antecedent of behavioral intention, ease of operation, and the perceived benefits of technology applications increased the frequency and duration of use of online applications [33]. This study indicates that perceived enjoyment has a positive effect on attitudes on the Grab Health application. Perceived enjoyment is the degree to which information system application activity can affect a person, regardless of previously known activity. Information systems are considered to help with tasks, have ease of use, and provide pleasure. $\mathrm{H} 2$ is supported. This 
research supports [34], which identifies that online game applications provide joy and improve emotions, which increases the frequency and duration of their use [34]. These findings indicate that individual attitudes towards an application are influenced by emotional responses that reflect perceived enjoyment, in addition to functional features [35]. The findings of this study indicate that social influences have a positive impact on attitudes towards the Grab Health app. Hypothesis 3 is supported. Socialinfluence is the extent to which individuals feel that the people they consider essential are using the new system. Individuals tend to need the support of others when dealing with new information system applications. Individuals seek to change behavior to meet social-environmental pressures in the form of conformity, outreach, sales, marketing, persuasion, obedience, and leadership. This study supports [36], who found that the social influence on collectivist culture is higher than countries with a culture of individualism. The closeness of the relationship between online network users affects efforts to influence the use of information system applications. The proximity of the relationship makes it easier to influence others to use information system applications [37];[38]. This study indicates that perceived vulnerability does not affect attitudes towards the Grab Health application. H4 is not supported. Users have the belief that the Grab Health application provides benefits and security from bad risks that harm their work and privacy. This study does not support [30];[31];[8], which indicates that perceived vulnerability has a positive effect on attitudes towards information systems. Different backgrounds and research problems have an impact on differences in research results. During a pandemic, individuals reduce their activities outside the home because they avoid being infected with Covid-19 and need an online shopping application that is flexible, easy to operate, and fun. The Grab Health application has a question and answers feature about health, which is useful for users to find health information. The various benefits of the Grab Health application minimize threats received by users. The need to use online health service applications has increased compared to physical services in polyclinics and hospitals. The public tends to ignore concerns about the risk of misuse of private information from Grab Health, which is considered credible. The Grab Health application provides a sense of security, comfort, and has useful features for its users. The Grab Health application makes shopping and online consultation easy without leaving home.

\section{CONCLUSIONS AND IMPLICATIONS}

This research indicates that the belief and perception that the Grab Health application is beneficial because it has many features and guaranteed safety enhances individuals to use it. The Grab Health application is believed to pleasure shopping and makes it easy to find health information, which increases the user's perspective that the Grab Health application is beneficial and fun. Users of the Grab Health application influence their environment through close relationships with other people to use the Grab Health application. Various features that provide benefits and enjoyment to transact and seek information from trusted sources, reduce the potential for bad risks for users, the risk of misuse of personal information from Grab Health. The Grab Health application provides a sense of security, comfort, and has useful features for its users. The Grab Health application makes shopping and online consultation easy without leaving home. The Grab Health application needs to increase the credibility of the application by including the drug sales license and doctor's certification from the regulator. Increasing the number of products and product variations that are well-informed and easy to find has the impact of increasing the positive user experience. To make it easier for users to find information, improving the consultation with pharmacists feature is an attractive option for users.

The Grab Health application needs to increase the diversity of doctors in various expertise and specialties to make it easier for users to obtain health information.

\section{REFERENCES}

[1] G. M. Madhav N, Oppenheim B, "Pandemics: Risks, Impacts, and Mitigation. In: Jamison DT, Gelband H, Horton S, et al., editors. Disease Control Priorities: Improving Health and Reducing Poverty. 3rd edition. Washington (DC): The International Bank for Reconstruction and Development / T," vol. 17, 2017, [Online]. Available: https://www.ncbi.nlm.nih.gov/books/NBK525302/ doi: 10.1596/978-1-4648-0527-1_ch17.

[2] J. Sheth, "Impact of Covid-19 on consumer behavior: Will the old habits return or die?," J. Bus. Res., vol. 117, pp. 280-283, 2020, doi: 10.1016/j.jbusres.2020.05.059.

[3] R. Djalante et al., "Review and analysis of current responses to COVID-19 in Indonesia: Period of January to March 2020," Prog. Disaster Sci., vol. 6, p. 100091, 2020, doi: 10.1016/j.pdisas.2020.100091.

[4] A. Evandio, "Pemeriksaan Online Virus Corona Bisa Dilakukan Lewat GrabHealth.," 2020, [Online]. Available: https://teknologi.bisnis.com/read/20200323/266/1217120/pemeriksa an-online-virus-corona-bisa-dilakukan-lewat-grabhealth.

[5] A. R. Alshehri M.m Drew S., Alhussain T., "The Effects of Website Quality on Adoption of E-Government Service: An Empirical Study Applying UTAUT Model Using SEM. Australasian Conference On Information System," pp. 1-13., 2012.

[6] Preevena K. \& Thomas S, "Continuance Intention to Use Facebook: A Study of Perceived Enjoyment and TAM. Bonfring International Journal of Industrial Engineering and Management Science," vol. 4 No.1, 2014.

[7] B. Rana N., Dwivedi Y., Lal, "Factor Influencing Citizen's Adoption of an E-Goverment System: Validation of the Decomposed Theory of Planned Behavior. UK Academy for Information System Conference Proceedings.," vol. 14, 2015.

[8] Z. R. Zhao Y., Ni Q., "What Factors Influence the Mobile Health Service Adoption? A Meta-Analysis and the Moderating Role of Age," Int. J. Inf. Manage., vol. 43, pp. 342-350, 2018.

[9] J. Hamari and J. Koivisto, "Why do people use gamification services?," Int. J. Inf. Manage., vol. 35, no. 4, pp. 419-431, 2015, doi: 10.1016/j.ijinfomgt.2015.04.006. 
[10] H. A. Mobley W., Horner S., "An Evaluation of Precursos of Hospital Employee Turnover.," J. Appl. Psychol., vol. 63 No.4, pp. 408-414, 1978.

[11] M. Tharhini A., Scott M., Sharma S., Abassi, "Differences in Intention to Use Educational RSS Feeds BetweenLebanese and British Students: A Multi-Group Analysis Based on the Technology Acceptance Model," Electron. J. e-Learning, vol. 13 No. 1, pp. 14 29, 2015.

[12] Liaw S.S. \& Huang H.M., "An Investigation of User Attitudes Toward Search Engines as an Information Retrieval Tool.," Comput. Hum. Behav., vol. 19, pp. 751-765, 2003.

[13] H. Lam T., Cho V., Qu, "A Study of Hotel Employee Behavioral Intentions Towards Adoption of Information Technology. Hospitality Management," vol. 26, pp. 49-65, 2007.

[14] D. Lin F., Fofanah S.S., Liang, "Assessing Citizen Adoption of eGoverment Intiatives in Gambia: A Validation of the Technology Acceptance Model in Infomation System Success," vol. 28, no. Government Information Quarterly, pp. 271-279, 2011.

[15] W. Nasri and L. Charfeddine, "Factors affecting the adoption of Internet banking in Tunisia: An integration theory of acceptance model and theory of planned behavior," J. High Technol. Manag. Res., vol. 23, no. 1, pp. 1-14, 2012, doi: 10.1016/j.hitech.2012.03.001.

[16] Scanlan T.K. \& Lewthwaite R, "Social Psychological Aspects of Competition for Male Youth Sport Participants: IV. Predictor of Enjoyment," J. Sport Psychol., vol. 8, pp. 25-335, 1986.

[17] Venkatesh V, "Deteminants of Perceived Ease of Use: Integrating Control, Intrinsic Motivation, and Emotion into the Technology Acceptance Model," Inf. Syst. Res., vol. 11 No. 4, pp. 342-365, 2000.

[18] Choi J. \& Kim S., "Is he Smartwatch an IT Product or a Fashion Product? A Study on Factors Affecting the Intention to Use Smartwatches. Computers in Human Behavior," vol. 63, pp. 777786, 2016.

[19] J. Zhang J., Liu B., Tang J., Chen T., Li, "Social Influence Locality for Modeling Retweeting Behaviors. Computer Science and Technology," pp. 2761-2767, 2013.

[20] X. Vankatesh V., Thong J., Xu, "Consumer Acceptance and use of Information Technology: Extending the Unified Theory of Acceptance and use of Technology.," Manag. Inf. Syst. Q., vol. 36 No.1, pp. 157-178, 2012.

[21] S. E. Chang, A. Y. Liu, and W. C. Shen, "User trust in social networking services: A comparison of Facebook and LinkedIn," Comput. Human Behav., vol. 69, pp. 207-217, 2017, doi: 10.1016/j.chb.2016.12.013

[22] M. Yusliza and T. Ramayah, "Determinants of Attitude Towards EHRM: an Empirical Study Among HR Professionals," Procedia Soc. Behav. Sci., vol. 57, pp. 312-319, 2012, doi: 10.1016/j.sbspro.2012.09.1191.

[23] N. P. Rana, Y. K. Dwivedi, M. D. Williams, and V. Weerakkody, "Adoption of online public grievance redressal system in India: Toward developing a unified view," Comput. Human Behav., vol. 59, pp. 265-282, 2016, doi: 10.1016/j.chb.2016.02.019.

[24] J. R. A. Mhina, M. G. Md Johar, and M. H. Alkawaz, "The Influence of Perceived Confidentiality Risks and Attitude on Tanzania Government Employees' Intention to Adopt Web 2.0 and Social Media for Work-Related Purposes," Int. J. Public Adm., vol. 42, no. 7, pp. 558-571, 2019, doi: 10.1080/01900692.2018.1491596.

[25] D. A. . Ojo A.O., Raman M., "Toward Green Computing Practices: A Malaysian Study of Green Belief and Attitude among Information Technology Professionals.," J. Clean. Prod., vol. 224, pp. 246-255, 2019, doi: 10.1016/j.clepro.2019.03.237.

[26] W. . Adger and P. M. Kelly, "Social Vulnerability to Climate Change and the Architecture of Entitlements. Mitigation and Adaptation Strategies for Global Change," vol. 4, p. pp. 253-266, 199AD.

[27] Johnston A.C. \& Warketin M, "Fear Appeals and Information Security Behaviors: An Empirical Study," vol. 34, no. MIS Quarterly, pp. 549-566, 2010.
[28] P. S. Siponen M., Mahmood M.A., “Employees' Adherence to Information Security Policies: An Exploratory Field Study. Information \& Management," vol. 51, pp. 217-224, 2014, doi: 10.1016/j.im.2013.08.006

[29] N. Mohamed and I. H. Ahmad, "Information privacy concerns, antecedents and privacy measure use in social networking sites: Evidence from Malaysia," Comput. Human Behav., vol. 28, no. 6, pp. 2366-2375, 2012, doi: 10.1016/j.chb.2012.07.008.

[30] U. Salleh N., Hussein R., Mohamed N., Karim N.S.A., Ahlan A.R., Aditiawarman, "Examining Information Disclosure Behavior on Social Network Sites Using Protection Motivation Theory, Trust and Risk," J. Internet Soc. Netw. Virtual Communities, vol. 2012, pp. 1-11, 2012, doi: 10.5171/2012.281869.

[31] X. Guo, X. Han, X. Zhang, Y. Dang, and C. Chen, "Investigating mhealth acceptance from a protection motivation theory perspective: Gender and age differences," Telemed. e-Health, vol. 21, no. 8, pp. 661-669, 2015, doi: 10.1089/tmj.2014.0166.

[32] Faham E. \& Asghari H, "Determinants of behavioral intention to use e-textbooks:AstudyinIran's agriculturalsector. Computers and Electronics in Algiculture," vol. 165, pp. 1-10, 2019.

[33] Rehman Z.U. \& Shaikh F.A, "Critical Factors Influencing the Behavioral Intention of Consumers towards Mobile Banking in Malaysia. Engineering, Technology \& Applied Science Research," Crit. Factors Influ. Behav. Intent. Consum. Towar. Mob. Bank. Malaysia. Eng. Technol. Appl. Sci. Res., vol. 10 No.1, pp. 52655269,2020

[34] N. Alzahrani A.I., Mahmud I., Ramayah T., Alfarraj O., Alalwan, "Extending the Theory of Planned Behavior (TPB) to Explain Online Game Playing Among Malaysian Undergraduate Students. Telematics and informatics," vol. 34, pp. 239-251, 2017.

[35] T. Zhang, C. Lu, and M. Kizildag, "Banking 'on-the-go': examining consumers' adoption of mobile banking services," Int. J. Oual. Serv. Sci., vol. 10, no. 3, pp. 279-295, 2018, doi: 10.1108/IJQSS-072017-0067.

[36] N. Jiménez and S. San-Martín, "Attitude toward m-advertising and m-repurchase," Eur. Res. Manag. Bus. Econ., vol. 23, no. 2, pp. 96102, 2017, doi: 10.1016/j.iedeen.2016.12.001.

[37] Verkijika S.F. \& Wet L.D, "E-government Adoption in sub-Saharan Afric. Electronic Commerce Research and Applications," vol. 30, pp. 83-93, 2018, doi: doi.org/10.1016/j.elerap.2018.05.

[38] H. N. Vahdat A., Alizadeh A., Quach S., "Would You Like to Shop Via Mobile App Technologi? The Technologi Acceptance Model, Social Factors and Purches Intention.," Aust. Mark. J., pp. 1-10, 2020. 